\title{
The Economic Analysis of Carbon Emissions: Evidence from China
}

\author{
Yu Kun Wang ${ }^{1}$, Li Zhang $^{1} \&$ We-me Ho ${ }^{1}$ \\ ${ }^{1}$ Department of Economics and Finance, Guangdong Ocean University Cunjin College, Guangdong Province, China \\ Correspondence: Department of Economics and Finance, Guangdong Ocean University Cunjin College, No. 1, Haida \\ Road, Mazhang District, Zhanjiang City, Guangdong Province, China.
}

Received: July 11, 2019

Accepted: July 29, $2019 \quad$ Available online: August 2, 2019

doi:10.11114/afa.v5i2.4422

URL: https://doi.org/10.11114/afa.v5i2.4422

\begin{abstract}
Transitioning away from coal supply is a cost-effective path to a low-carbon economy. Although many articles have considered the issue of manufacturers' production and emission of pollution. Few papers have discussed the interrelations among $\mathrm{CO} 2$ emissions, economic growth and coal supply on the cost of environmental degradation. This paper seeks to fill this gap by using some empirical tests including unit root, ARDL bounds test and impulse effect to check the causality among carbon emission, economic growth and coal supply The time series used in the model ranged from 1990 to 2016. We specifically take China as a case to analyze. The main results show that there exist only one-way positive causality between LGDP (dependent variable) and LCO2 (independent variable), in addition, we show China's GDP growth in recent years has gradually decoupled from $\mathrm{CO} 2$ emissions, in other words, the current growth of China's economy is not at the cost of worsening the environmental degradation, Furthermore, we outline that the generalized impulse response between LCO2 and LGDP is higher than that of LCOALSUPPLY and LGDP.
\end{abstract}

JFL Classification: H23, H26, P43, Q 53

Keywords: China, carbon emission, unit root, bounds test, cointegration

\section{Introduction}

According to the WHO statistics, air pollution poses a major threat to health and climate. The combined effects of ambient (outdoor) and household air pollution cause about 7 million premature deaths every year. More than $80 \%$ of people living in urban areas that monitor air pollution are exposed to air quality levels that exceed the WHO guideline level, with low- and middle-income countries suffering from the highest exposures. The major outdoor pollution sources include vehicles, power generation and industry.Many of the drivers of air pollution (i.e. combustion of fossil fuels) are also sources of high $\mathrm{CO}_{2}$ emissions. Some air pollutants such as ozone and black carbon are short-lived climate pollutants that greatly contribute to climate change. Since the early 2000s, Asia was the dominant source of emissions, reaching $17.4 \mathrm{GtCO} 2$ in 2016, twice the level of the Americas and three times that of Europe. China accounted for more than one half of emissions in Asia in 2016 followed by India with 12\%. Li et al.(2019) utilize data envelopment analysis(DEA) to measure the total level of ecological construction in China and find that the total level of ecological construction of China is still low. According to the International Energy Agency (IEA)statistics, in 2016, global CO2 emissions from fuel combustion were $32.31 \mathrm{GtCO} 2$, broadly similar to levels in 2015. Looking back further, emissions have more than doubled since the early seventies and increased by around $40 \%$ since 2000 . According to the analysis of International Energy Agency(IEA), most of these increases are linked to increased economic output. Despite emissions being relatively stable between 2013 and 2016, initial IEA analysis showed that in 2017 emissions increased by around $1.5 \%$, led by China, India and the European Union.

The remainder of this paper is organized as follows. Section 2 discuss the causality and interrelations among CO2 emissions, economic growth and coal supply in China's case, the time series used in the model ranged from 1990 to 2016. Section 3 examines the long-term stability and the impulse response effect. Section 4 concludes and discussion.

\section{Literature Review}

Stern's report (2006) shows that if the world invested $1 \%$ of GDP per year to combat global warming, it would avoid 5\% to $20 \%$ of GDP loss per year in the future.

Panayotou(1997) samples data from 30 countries from 1982 to 1994 and found that low-income policies had a positive effect on improving the environment, with the increase of income level, the effect became more obvious. However, the 
faster the economic growth, the higher the population density, the higher the environmental cost of economic growth. Harbaugh et al.(2002) show that the link between economic growth and environmental pollution is not only influenced by economic factors, but also by sample selection and research methods. Bruyu(1997) selectes data from developed countries in the 1980s to analyze, which showed that changes in economic structure had no significant effect on SO2 emissions, but in the high-income stage, environmental policies formed by international agreements could well explain the negative correlation between environment and income. Grossman(1995) regards urban air pollution and oxygen content in river water as environmental indicators. Through regression analysis, it is concluded that economic growth causes deterioration of environmental indicators in the low-income stage, and improves with economic growth in a certain stage, and the inflection point occurs at the income level of \$8,000 (some examples are Sherry 2008, David 2004, Gurluk 2009 ). Copeland (2004) analyzes the relationship among economic growth, international trade and environmental pollution, and found that on the inverted U-shaped curve of economic growth and environmental pollution, international trade and capital flow had a great impact on environmental pollution. Llorca and Meunie(2009) obtain the N-curve relationship between $\mathrm{SO} 2$ emission and per capita income. In addition, due to the concentration of PM2.5 are regularly measured from fixed-site, population-oriented monitors located within the metropolitan areas. Although PM is measured at many thousands of locations throughout the world, the amount of monitors in different geographical areas vary, with some areas having little or no monitoring. Annual urban mean concentration of PM2.5 is estimated with improved modelling using data integration from satellite remote sensing, population estimates, topography and ground measurements. Therefore, it is acknowledged that the estimates of PM2.5 for data-poor countries may be relatively imprecise, measurements of PM2.5 are not available, and this imprecision can result in apparently abrupt changes in air pollution levels at borders with data-poor countries. For enhanced accuracy of modelled data it is important that countries continue and/or improve their ground measurements. Thus, unlike the bulk of the literature, this paper intends to use $\mathrm{CO} 2$ emissions, the main gas responsible for global warming, as an indicator of air pollution in a country (Jeyhun et al.,2018).

\section{Methodology and Analyses}

Being carbon neutral is increasingly seen as good corporate or state social responsibility and a growing list of corporations, cities and states are announcing dates for when they intend to become fully neutral. As we know, many of China's energy needs are directly derived from the supply of coal. Thus, reducing carbon emissions while keeping a high pace of economic growth lies at the heart of China's sustainable development plan. Zhang and Da (2015) indicate that economic growth appears as an important driver of carbon emissions increase in the past decades, while the decrease of energy intensity and the cleaning of final energy consumption structure play significant roles in curbing carbon emissions; Koretelainen(2008) proposed to use EPI to evaluate the effectiveness of environmental and economic policies, but EPI only considers environmental quality and neglects economic growth. In contrast with the traditional dynamic eco-efficiency analysis (Kuosmanen and Kortelainen,2005, 2007; Anderson and Peterson, 1993; Korhonen and Luptacik,2004 ), we focus on the correlation between carbon dioxide emissions and economic growth rate and coal production, and the prediction of dynamic time series of carbon dioxide /GDP.We use empirical analysis to discuss the effects of the above variables on carbon dioxide emissions, where carbon emissions are measured in production-basedemissions, MtCO2 and GDP are measured in USD billion in 2010. In addition, energy supply from coal is measured in Ktoe, respectively. The input data of GDP, coal supply and $\mathrm{CO} 2$ emissions in this paper are mainly referred to the International Energy Agency.

Initially, the time series of carbon emissions, gross domestic product and coal energy supply are logarithmic as shown in Figure 1, denoting that the time series of all three variables present an increasing trend, and those sequences show that the mean values are varying in different periods, we then judge that the sequences are non-stationary.

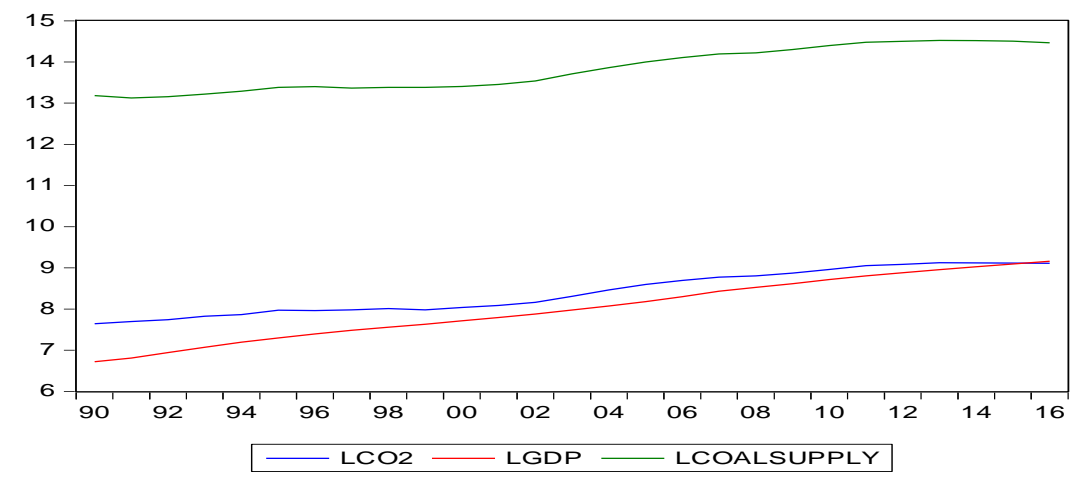

Figure 1. Time trend data on CO2 emissions, GDP, Coal Supply in logarithmic form for China, Source. International Energy Agency 
In figure 1, LGDP, LCO 2 and LCOAL SUPPLY represent the logarithmic functions of GDP, CO2 and COALSUPPLY, respectively. Granger and Newbold (1974) proposes false regression. Nelson and Plosser (1982) find that many of the original sequences have non-stationary characteristics. Therefore, before conducting empirical research on time series analysis, it is essential to tackle with unit root problems as follows. (Dickey and Fuller,1979; Enders,2010; Phillips and Perron,1988; Kwiatkowski, et.al,1992 ).

\subsection{Unit Root Test}

At first we use the period 1990 to 2016 as an analysis period to verify the existence of unit root. The results of unit root tests are presented in Table 1.We use ADF and PP unit root methods, the LCO2 appeares stationary at the 2st-differenced form under $1 \%$ significant level, depicting the logged variables are I(2), and the LGDP also appeares stationary at the 2st-differenced form under $1 \%$ significant level, explaining the logged variables are also I(2). Furthermore, we use the KPSS unit root method, the LCoalSupply appeares stationary at $\mathrm{I}(0)$ under $5 \%$ and $10 \%$ significant level, respectively. In theory, the linear combination mode produced by the same order sequence may form a co-integration relationship with the original sequence of different orders. Since the order of the ADF and PP unit root test are $\mathrm{I}(2)$, whereas the order of KPSS unit root test is $\mathrm{I}(0)$. Thus, we can not proceed with Johansen co-integration test. (Engle and Granger,1987; Johansen and Juselius,1990).

Table 1. Performance of unit root test of LCO2, LGDP, COALSUPPLY

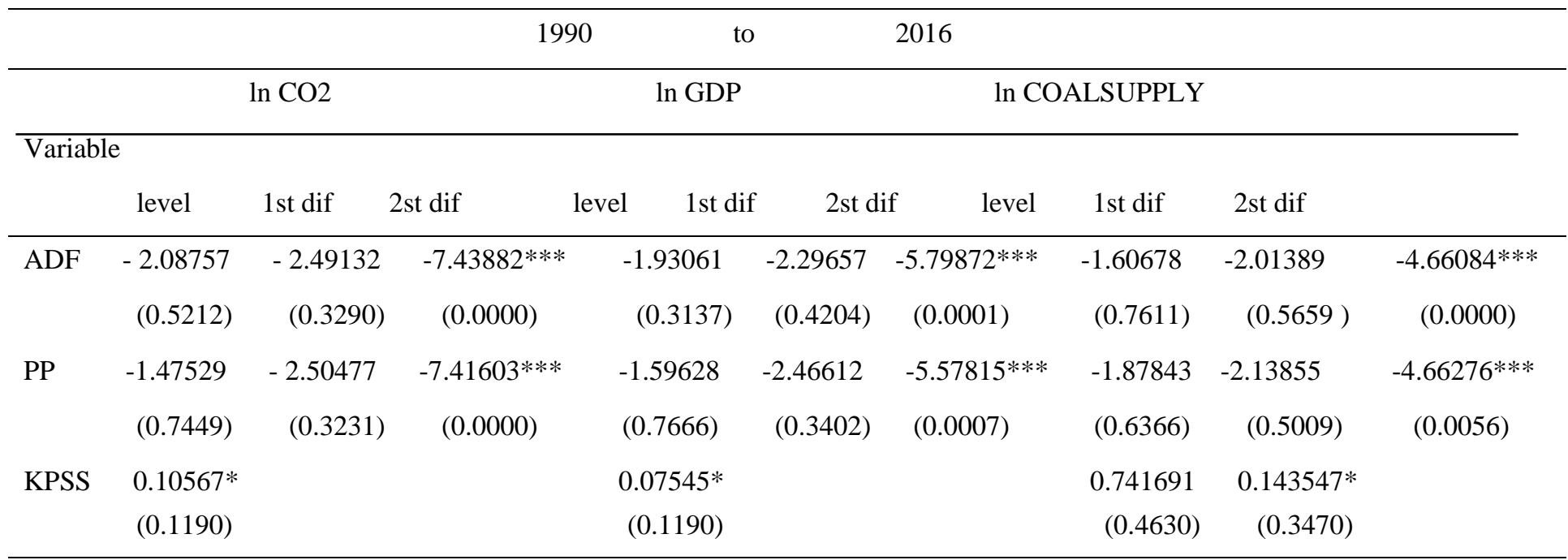

Notes: Variables in logarithmic form ; when adopting ADF test and PP test, *** stand for rejection of null hypothesis at $1 \%$ significance level, respectively, when adopting KPSS test, * stand for acceptance of null hypothesis at $10 \%$ significance level.

\subsection{ARDL Bounds Test}

Nevertheless, Pesaran et al (2001) propose the ARDL bounds test for different order of variables, the advantage is the order of variables need not be considered in the co-integration process, that is, whether $\mathrm{I}(0)$ of the stationary state or $\mathrm{I}(1)$ and I(2) with a unit root will not affect the testing results, and it can also clearly distinguish between the two variables which are endogenous and which are independent. The boundary test proposed by Pesaran et al. (2001) is not restricted by the order of variables. It can clearly judge whether there exists a long-term equilibrium relationship only by the critical value, and can distinguish which is endogenous variable and which is independent variable. There are five models for the boundary test method. In this paper, the more general Case III model is adopted as follows.

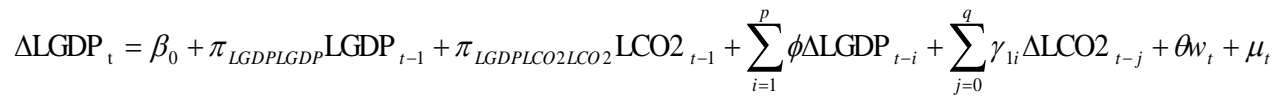

Eq.(1) denotes that $\pi_{L G D P L G D P}$ and $\pi_{\angle G D P L C O 2 L C O 2}$ are long-term parameters, $\theta w_{t}$ is a virtual vector of exogenous variables, the normal and deferred values of $\triangle \mathrm{LGDP}$ and $\triangle \mathrm{LCO} 2$ are short-term dynamic structures. According to ARDL model, it is assumed that there are two variables in the economic system, and the long-term relationship between 
them can not be known from previous information. Thus, we list the Eq.(2) and Eq.(3) as dependent variables, respectively.

$$
\begin{aligned}
& \Delta \mathrm{LGDP}_{\mathrm{t}}=\alpha_{1}+\sum_{i=1}^{p} \beta_{1 i} \Delta \mathrm{LGDP}_{t-i}+\sum_{j=0}^{q} \gamma_{1 j} \Delta \mathrm{LCO}_{t-j}+\theta_{1 L G D P} \mathrm{LGDP}_{t-1}+\theta_{2 L G D P} \mathrm{LCO}_{t-1}+\varepsilon_{1 t} \\
& \Delta \mathrm{LCO}_{2}=\alpha_{2}+\sum_{i=0}^{p} \beta_{2 i} \Delta \mathrm{L} \mathrm{GDP}_{t-i}+\sum_{j=1}^{q} \gamma_{2 j} \Delta \mathrm{LCO}_{t=j}+\theta_{1 L C \circlearrowright} \mathrm{L} \mathrm{GDP}_{t-1}+\theta_{2 L C \circlearrowright} \mathrm{LCO}_{t-1}+\varepsilon_{2 t}
\end{aligned}
$$

Clearly, other causal analysis of LCO 2 and LCOALSUPPLY, and the casuality between LCOALSUPPLY and LGDP can also be derived from this concept. Taking the bounds test as an example, the null hypothesis is that there is no co-integration relationship among variables. Referring to Keho (2010b), we utilize ADRL bounds test for Pesaran co-integration verification, and test the cointegration approach among those variables for China over a time period ranging from 1990 to 2016.

From Table 2, we show that under a significant level of 5\%, when LCO 2 is dependent variable, it is impossible to reject the null hypothesis that there is no co-integration, and under a significant level of 5\%, when LGDP is dependent

variable, the F-statistic of joint verification is 10.09618 higher than the upper critical value of 5.73 , indicating a significant rejection of null hypothesis, which means that there is a unidirectional co-integration causality between LGDP and LCO2.

Hypothesis 1: At 5\% significant level, F (LCO 2/LGDP) LCO 2 is 3.3593, which is lower than the lower critical value of 4.94, but F (LGDP/LCO 2) LGDP is 10.0962, which is higher than the upper critical value of 5.73, indicating that only one-way positive causality exists between LGDP (dependent variable) and LCO2 (independent variable).

Hypothesis 1 shows that when Johansen's co-integration relationship does not exist between LCO 2 and LGDP, the ARDL Bounds test displays that at a significant level of 5\%, co-integration exists only in the regression equation with LGDP as the interpreted variable. That is to say, when we utilize ADRL bounds test for Pesaran co-integration verification,testing the cointegration approach among those variables for China over a time period ranging from 1990 to 2016, we find that LCO2 affect LGDP, but the causality does not work in reverse. That is to say, as LGDP is a dependent variable, it has one-way co-integration with $\mathrm{LCO} 2$, the independent variable.

In addition, when LGDP and LCOALSUPPLY are mutually dependent variables, yet the F-statistic value of LGDP is 1.2838 and the F-statistic value of LCOAL SUPPLY is 2.7629, they are lower than the threshold value of 5\% significant level of 4.94, which means that the statistics are not significant and the null hypothesis that there is no co-integration can not be rejected, that is, there does not exist long-term equilibrium relationship between LGDP and LCOALSUPPLY.

Next, we discuss that when LCO2 and LCOALSUPPLY are mutually dependent variables, there exist a co-integration relationship between them. In the following we discuss whether there exist long-term relationship among LGDP, LCO 2 and LCOALSUPPLY. 
Table 2. ARDL bounds test result

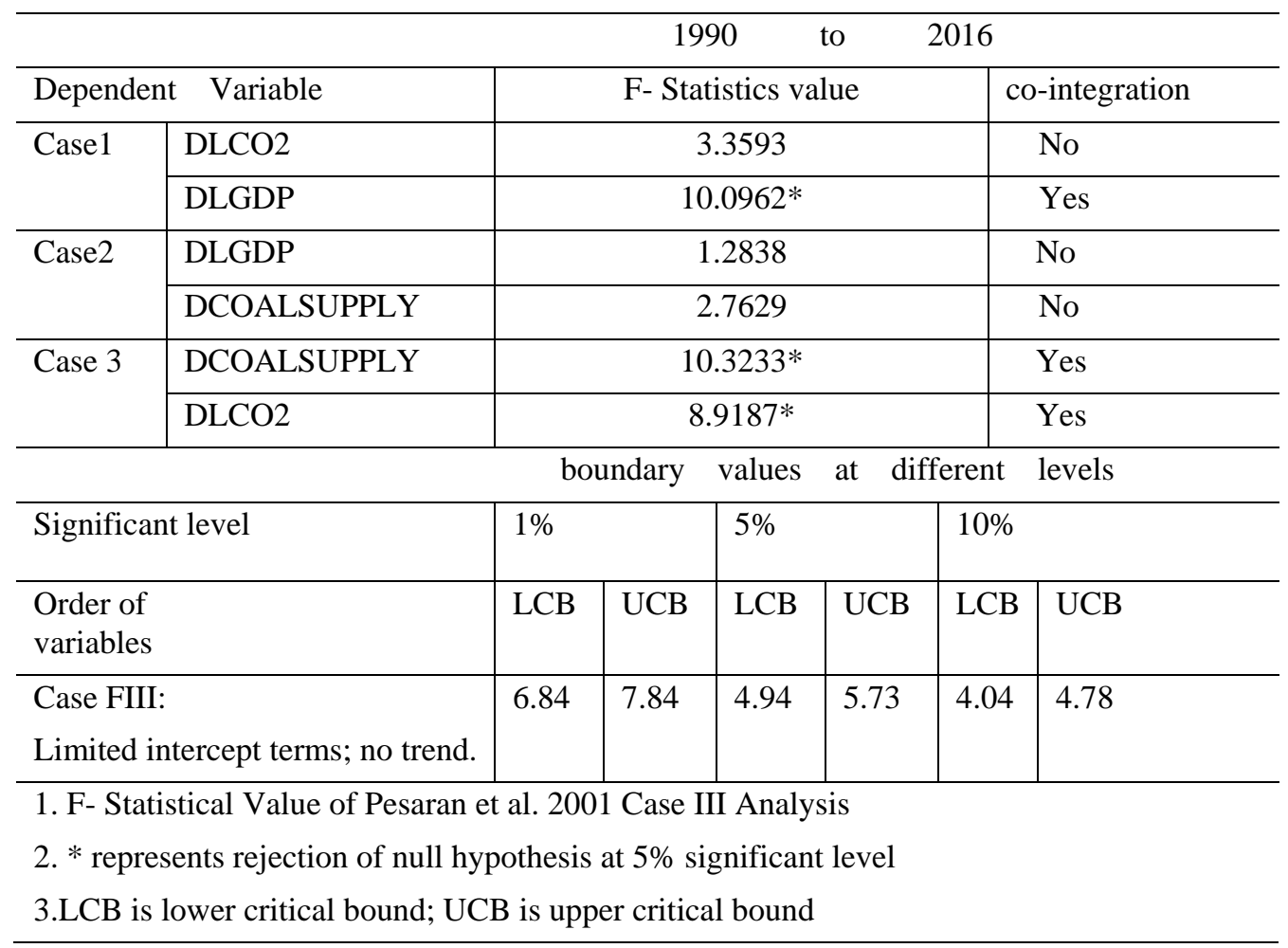

\subsection{Long-Term Interrelation Analysis}

As can be seen from Eq.(4), the long-term correlation coefficient between LGDP and LCO 2 is $-\frac{\theta_{2}}{\theta_{1}}$ : and the long-term relationship coefficient between LCO2 and LCoalsupply is $-\frac{\theta_{3}}{\theta_{1}}$;

$$
\Delta \mathrm{LGDP}_{\mathrm{t}}=\alpha_{1}+\sum_{i=1}^{p} \beta_{1 i} \Delta \mathrm{LGDP}_{t-i}+\sum_{i=0}^{q} \gamma_{1 i} \Delta \mathrm{LCO} 2_{t-i}+\theta_{1} \mathrm{LGDP}_{t-1}+\theta_{2} \mathrm{LCO}_{t-1}+\varepsilon_{1 t}
$$

Other causal analysis of LCO 2 and LCOALSUPPLY, and the causality between LCOALSUPPLY and LGDP can also be derived from this concept. Due to the lack of Johansen relationship among those variables, we estimate the long-term relevance by using OLS and ARDL bounds test (see Pesaran et al,2001). During 1990-2016, when LGDP is the dependent variable, the long-term relevance estimated by utilizing LGDP as the dependent variable and LCO2 as the independent variable, the result is listed in table 3 which shows that LGDP and LCO 2 have a long-term positive relevance at the $1 \%$ significant level under both OLS and ARDL bounds test. In other words, from a long-term perspective, LGDP and LCO 2 present a one-way long-term positive relevance, the increase of LCO 2 leads to the increase of LGDP, but an increase in LGDP does not necessarily lead to an increase in LCO2.

As we observe China's CO2 emissions in 2013, 2014, 2015 and 2016 are 9191, 9125, 9103 and 9057 tons respectively, showing a decreasing trend year after year. GDP based on billion 2010 USD, in 2013, 2014, 2015, 2016 are 7767, 8333, 8908 and 9505 respectively, showing an increasing trend year after year, denoting that China's GDP growth in recent years has gradually decoupled from $\mathrm{CO} 2$ emissions, our analytic results correspond to the concept of absolute decoupling between economy and environment proposed by Brown (2003) and Mikayilov et al. (2018).

The above GDP, Coal Supply and CO2 data coming from International Energy Agency(IEA) are consistent with our analysis in Table 3. Nevertheless, the third case in Table 3 shows that when CO2 is a dependent variable, both ARDL and OLS methods show that Coal Supply has a significant positive correlation with CO2 emissions. 
Table 3. Estimation of long-term relationship

\begin{tabular}{l|l|c|c}
\hline \multicolumn{2}{c}{$1990 \quad$ to 2016} \\
\hline \multirow{2}{*}{ Dependent } & Variable & OLS & ARDL \\
\hline Case 1 & LGDP & Independent Variable & Independent Variable \\
\cline { 3 - 4 } & & LCO2 & LCO2 \\
\cline { 3 - 4 } & & $4.1371^{* * *}$ & $1.2144 * * *$ \\
\hline Case 2 & LCOAL SUPPLY & $(7.424118)$ & $(3.608659)$ \\
& & LCO2 & LCO2 \\
\cline { 3 - 4 } & & $0.8909 * * *$ & $1.8079 * * *$ \\
& & $(8.906293)$ & $(3.769119)$ \\
\hline Case 3 & LCO2 & LCOAL SUPPLY & LCOAL SUPPLY \\
& & $0.9149 * * *$ & $0.6890^{* *}$ \\
& & $(8.906293)$ & $(2.931563)$ \\
\hline
\end{tabular}

1. OLS is estimated by the least square method and ARDL long-term relationship coefficient is estimated by bounds test equation.

2.variables in logarithmic form ; *,**,*** stand for at $1 \%, 5 \%$ and $10 \%$ significance level; the number in brackets is the $\mathrm{t}$-statistic of the estimated parameter

Figure 2 and Figure 3 show that the proportion of CO2/GDP decreases year by year, and the proportion of COALSUPPLY/GDP decreases year by year, respectively. The empirical results indicate that China may have made some improvements in environmental protection in recent year, especially in carbon emission control, it could be that higher income levels lead to increased demand for environmental protection (Michael,1995).

As mentioned above, we show that China's CO2 emissions has gradually decoupled from GDP, which is consistent with the Kuznets Curve(Grossman and Krueger,1991) and The International Energy Agency statistical data. In addition, Table 4 shows the rising and falling trend of the four cycles. The flunctuation of the third and fourth cycles in Figure 2 show that it may be related to the implementation of automatic monitoring of urban air quality in China cities at the end of 2005 and the formal incorporation of environmental protection expenditure into the national budget since 2006.

Hypothesis 2: In comparison with IEA(International Energy Agency) data and our empirical results about China's economic growth and $\mathrm{CO} 2$ emissions in the past four years(2013-2016), see Table 3 and Figure 2, showing up the proportion of CO2/GDP decreases year by year, and the proportion of COALSUPPLY/GDP decreases year by year,respectively,depiciting that China's GDP growth in recent years has gradually decoupled from $\mathrm{CO} 2$ emissions.

Fixed Length Symmetric (Baxter-King) Filter

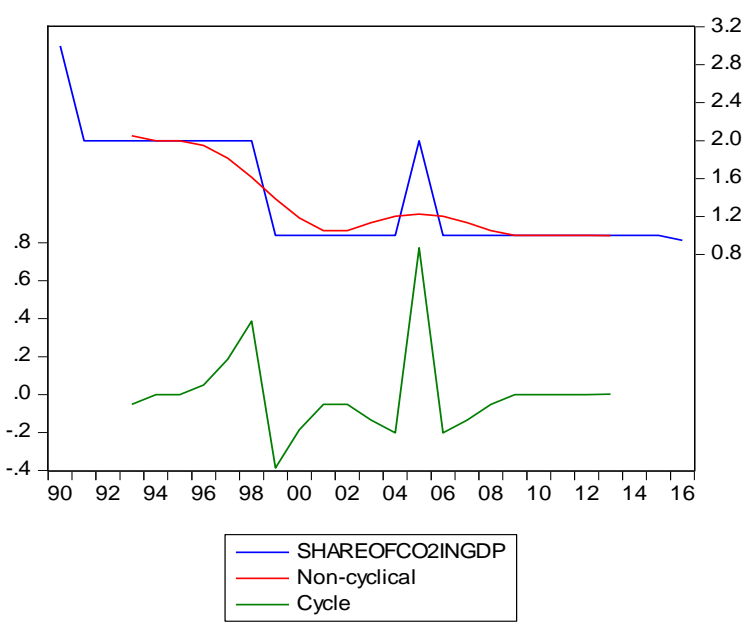

Frequency Response Function

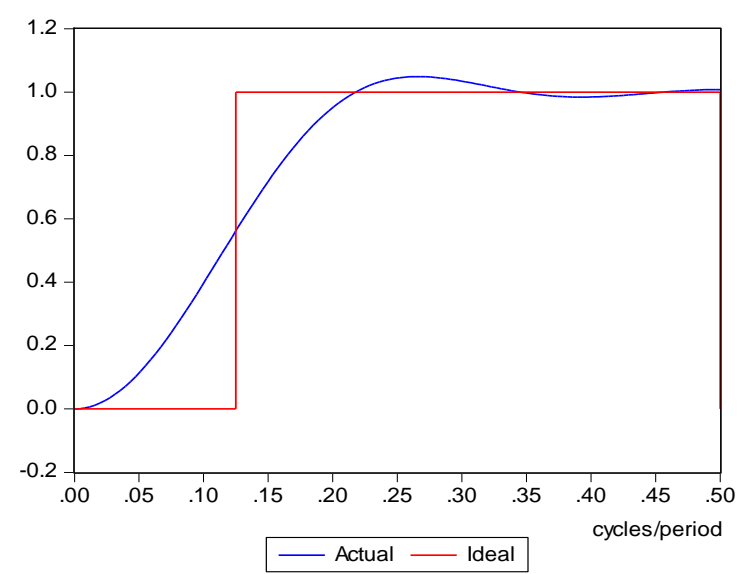

Figure 2. Bandpass Filter Decomposition of CO2/GDP,China,1990-2016 
Fixed Length Symmetric (Baxter-King) Filter

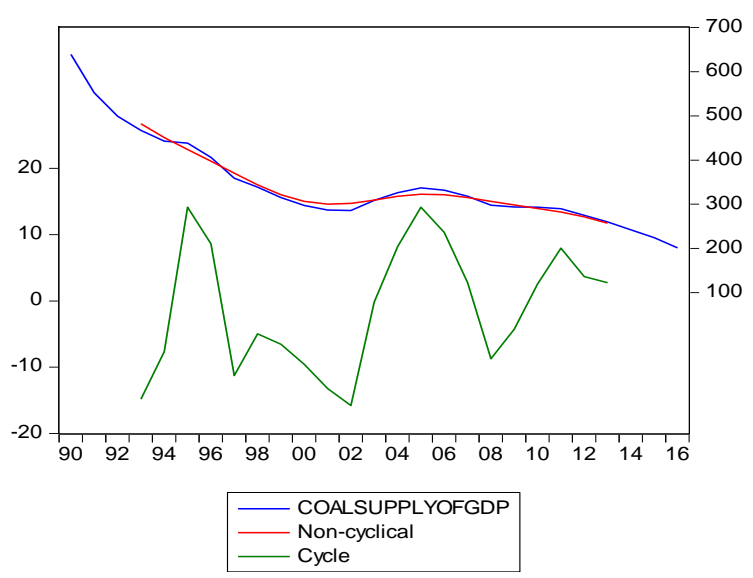

Frequency Response Function

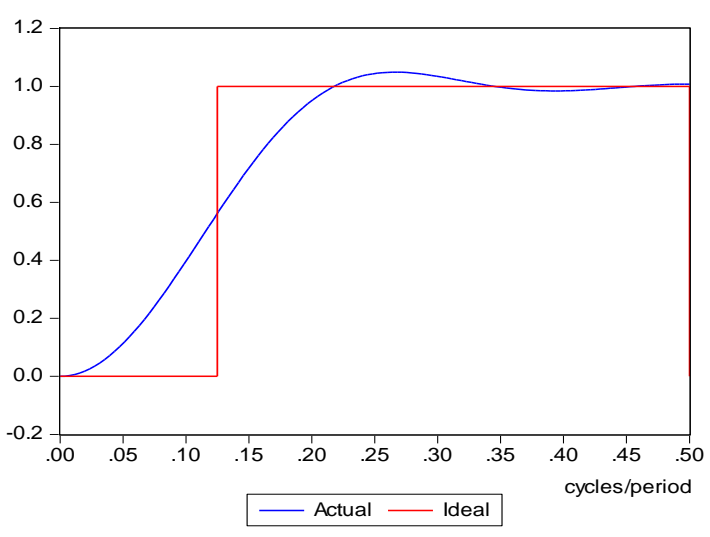

Figure 3. Bandpass Filter Decomposition of COALSUPPLY/GDP,China,1990-2016

Table 4. Estimation of long-term relationship

\begin{tabular}{|c|c|c|c|c|c|}
\hline & & 1990 & 201 & & \\
\hline $\mathrm{CO} 2 / \mathrm{GDP}$ & \multicolumn{2}{|c|}{ unit: (kg CO2/2010 USD) } & \multicolumn{2}{|c|}{ Variable : COALSUPPLY/GDP } & \\
\hline $\mathrm{BP}$ & interval & trend & $\mathrm{BP}$ & interval & trend \\
\hline \multirow{2}{*}{$\begin{array}{l}\text { First } \\
\text { cycle }\end{array}$} & 1993.1-1998.2 & increasing & \multirow{2}{*}{$\begin{array}{l}\text { First } \\
\text { cycle }\end{array}$} & 1993.2-1995.1 & increasing \\
\hline & $1998.3-1999.3$ & decreasing & & 1995.2-1997.2 & decreasing \\
\hline \multirow{2}{*}{$\begin{array}{c}\text { Second } \\
\text { cycle }\end{array}$} & 1999.4-2001.2 & increasing & \multirow{2}{*}{$\begin{array}{l}\text { Second } \\
\text { cycle }\end{array}$} & 1997.3-1998.11 & increasing \\
\hline & 2001.3-2004.4 & decreasing & & $1998.12-2002.7$ & decreasing \\
\hline \multirow{2}{*}{$\begin{array}{l}\text { Third } \\
\text { cycle }\end{array}$} & $2004.5-2005.1$ & increasing & \multirow{2}{*}{$\begin{array}{l}\text { Third } \\
\text { cycle }\end{array}$} & $2002.8-2005.1$ & increasing \\
\hline & 2005.2-2006.3 & decreasing & & 2005.2-2008.2 & decreasing \\
\hline \multirow{2}{*}{$\begin{array}{c}\text { Fourth } \\
\text { cycle }\end{array}$} & 2006.4-2009.8 & increasing & \multirow{2}{*}{$\begin{array}{c}\text { Fourth } \\
\text { cycle }\end{array}$} & 2008.3-2011.11 & increasing \\
\hline & 2009.9-2014.11 & non-decreasing & & $2011.12-2014.12$ & decreasing \\
\hline
\end{tabular}

\section{Impulse Effect Test}

Next, we discuss the interaction between LCO2, LGDP and LCoal Supply, respectively. As mentioned earlier, due to the order of integration among those variables are not the same order. Thus, we utilize structural VAR (Vector Autoregressive ) and treat all variables as endogenous variables to overcome the doubts about the identification of endogenous and exogenous variables problem (Sims,1980). Owing to Sims (1980) method has the problem of variable ranking, that is to say, the order of variables entering VAR model will lead to different results for impulse response function analysis or prediction error variance decomposition. This is so called the ranking problem in the relevant literature. Whereas the general prediction error variance decomposition (Koop, Pesaran, Potter, 1996) and the general impulse response analysis (Pesaran and Shin, 1998) can solve the ranking problem. On the other hand, when a shock is applied to the error term of each variable in each equation, the effect of the shock on structural VAR can be observed over a period of time. Then, if the VAR system is stable, the shock will gradually disappear over time. It is known that when LCOALSUPPLY and LGDP are mutually dependent variables, there is no co-integration relationship. Nevertheless, LGDP is dependent variable, LCO2 is independent variable, there exist a long-term, stable and one-way integration. From Figure 4, we can see that the impact of LCO 2 on LGDP is zero at the beginning, except for the negative impact effect of the second period. After the third period, the impact of LCO 2 on LGDP obviously maintains a positive proportional correlation. Even though it is the tenth period, the impact of LCO 2 on LGDP still exists and does not decrease gradually. On the other side, we can see from Figure 5, even though it is the tenth period, the impact of LCOALSUPPLY on LCO2 still exists and does not decrease gradually. So we can get the following Hypothesis 3 . 


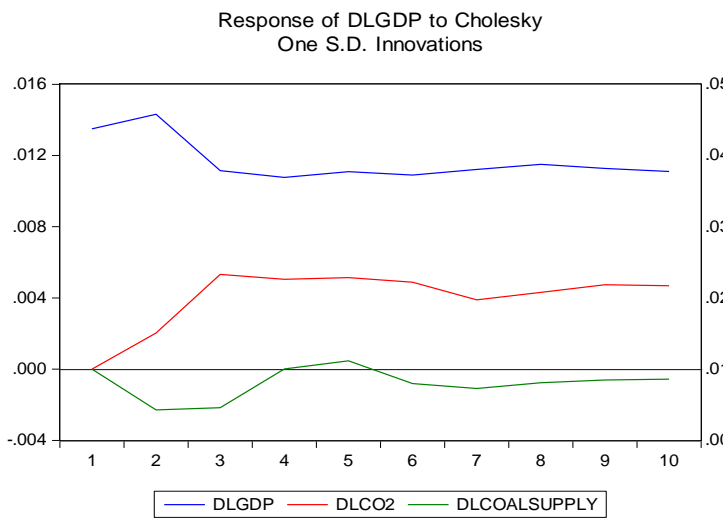

Figure 4. Impulse of LCO2 on LGDP
Response of DLCO2 to Cholesky

One S.D. Innovations

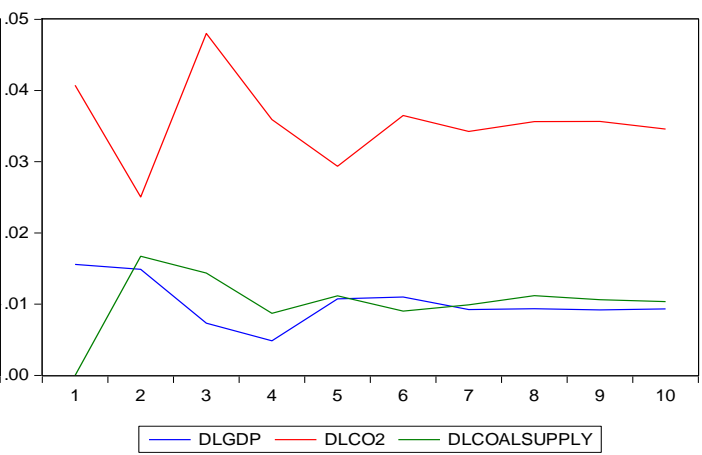

Figure 5. Impulse of LCOALSUPPLY on LCO2

Hypothesis 3: The unexpected impact variation of LCO2 on LGDP is higher than that of LCOALSUPPLY on LGDP, even though it is the tenth period, the impact of LCO 2 on LGDP still exists and does not decrease gradually.

Hypothesis 3 is explored using a generalized variance decomposition method(Koop et. al, 1996). As we know, prediction error variance decomposition can estimate the proportion of prediction error variation of a variable which is explained by the prediction error variation of other variables. Although the shock response function is similar to the information provided by the prediction error variance decomposition, the difference is that the prediction error variance decomposition is estimated under the condition of a given factor variable, calculating the magnitude of the change when it is impacted by itself and other variables. (Lütkepohl, 2007).

$$
\begin{gathered}
\left\{e_{L G D P, t}\right\}=\frac{\sigma_{L G D P\left[\Psi_{L G D P L G P P}(0)^{2}+\Psi_{L G D L G D P}(1)^{2}+\cdots+\Psi_{L G D P L G P P}(n-1)^{2}\right]}}{\sigma_{L G D P}^{2}(n)} \\
\left\{e_{L C O 2, t}\right\}=\frac{\sigma_{L C O 2\left[\Psi_{L G D P L C O 2}(0)^{2}+\Psi_{L G D P L G C O 2}(1)^{2}+\cdots+\Psi_{L G D P C O 2}(n-1)^{2}\right]}^{2}}{\sigma_{L G D P}^{2}(n)} \\
\left\{e_{L C O A L S U P P L Y, t}\right\}=\frac{\sigma_{L C O A L S U P P L Y}^{2}\left[\Psi_{L G D P C O A L S U P P L Y}(0)^{2}+\Psi_{L G D P L C O A L S U P P L Y}(1)^{2}+\cdots+\Psi_{L G D P L C O A L S U P P L Y}(n-1)^{2}\right]}{\sigma_{L G D P}(n)}
\end{gathered}
$$

Eq.(5), (6), (7) are the decomposition of predictive error variance of $L G D P_{t}$ which adds up to $100 \%$. It can be that how much percentage of $L G D P_{t}$ predicts future n period variance comes from its own $L G D P_{t}$ and how much percentage comes from $L C O 2_{t}$ and $L C O A L S U P P L Y_{t}$. If the $L C O 2_{t}$ and $L C O A L S U P P L Y_{t}$ shocks do not explain the prediction error variance of $L G D P_{t}$ at all during the prediction period, then the VAR vector $\left\{L G D P_{t}\right\}$ sequence is an exogenous variable. Conversely, if the $L C O 2_{t}$ and $L C O A L S U P P L Y_{t}$ shocks fully explain the prediction error variance of $L G D P_{t}$ the VAR vector $\left\{L G D P_{t}\right\}$ sequence is an endogenous variable. Through the VAR analysis, we can see from Table 5, the unexpected impact variation of LCO2 and LCOALSUPPLY on LGDP, respectively. At the beginning, the percentage of LGDP explained by LCO2 and LCOALSUPPLY is small, when looking forward to the forecast of eighteenth period. LCOALSUPPLY can explain only $2.62 \%$ of the variation of LGDP prediction errors. but LCO 2 can explain $30.22 \%$ of the variation of LGDP prediction error, indicating that the LCO2 has a higher correlation with LGDP. 
Table 5. Variance Decomposition of DLGDP (Ordering for Cholesky)

\begin{tabular}{ccccc}
\hline Period & S.E. & DLCO2 & DLCOALSUPPLY & DLGDP \\
\hline 1 & 0.011191 & 0.00000 & 0.00000 & 100.0000 \\
2 & 0.015148 & 5.577518 & 0.158847 & 94.26363 \\
3 & 0.018204 & 17.06364 & 0.173849 & 82.76251 \\
4 & 0.020090 & 21.57332 & 1.104533 & 77.32215 \\
5 & 0.021362 & 26.79366 & 1.775456 & 71.43089 \\
6 & 0.021985 & 29.01971 & 2.220768 & 68.75952 \\
7 & 0.022226 & 29.82650 & 2.510608 & 67.66289 \\
8 & 0.022306 & 30.16703 & 2.589579 & 67.24339 \\
9 & 0.022321 & 30.21047 & 2.616454 & 67.17307 \\
10 & 0.022322 & 30.21611 & 2.620449 & 67.16344 \\
11 & 0.022322 & 30.21596 & 2.620448 & 67.16360 \\
12 & 0.022323 & 30.21757 & 2.620455 & 67.16197 \\
13 & 0.022323 & 30.21828 & 2.620740 & 67.16098 \\
14 & 0.022323 & 30.21889 & 2.620895 & 67.16021 \\
15 & 0.022323 & 30.21907 & 2.620945 & 67.15998 \\
16 & 0.022323 & 30.21909 & 2.620965 & 67.15994 \\
17 & 0.022323 & 30.21910 & 2.620967 & 67.15993 \\
18 & 0.022323 & 30.21910 & 2.620967 & 67.15993 \\
\hline
\end{tabular}

\section{Conclusions and Discussion}

In comparison with traditional literature, the major findings of this paper can be listed as follows: Clearly, when LGDP is a dependent variable, it has one-way co-integration with LCO 2, the independent variable, as we think, it could be that higher income levels lead to increasing demand for environmental protection. Next, we show the increase of LCO2 emissions at the initial stage results in the decrease of LGDP, the relationship between them appears as a "J-curve" shape on a time-series graph. However, whether the deterioration of air quality attributed to the reduction of outgoing consumption at the initial stage. So far, due to lack of relevant consumption environment empirical research in discussing the matter, thus, we consider this is the focus of future research . In addition,during the past four years, we find, although the $\mathrm{CO} 2$ emission in China has gradually decoupled with the GDP, the rise in income level still increases emissions more or less. In this regard, how the effectiveness of environmental protection tax implemented since 2018 in China is an important index worth studying in the future.

\section{References}

Agliardi, E. (2011). Sustainability in Uncertain Economics. Environmental \& Resource Economics, 48(1), 71-82. https://doi.org/10.1007/s10640-010-9398-x

Anderson, P., \& Peterson, N. C. (1993). A Procedure for Ranking Efficient Units in Data Envelopment Analysis. Management Science, 39(10), 1261-1264. https://doi.org/10.1287/mnsc.39.10.1261

Auffhammer, M., \& Ryan, K. (2011). Clearing the Air ? The Effects of Gasoline Content Regulation on Air Quality. American Economic Review, 101(6), 2687-2722. https://doi.org/10.1257/aer.101.6.2687

Baron, D. P. (2001). Private Politics: Corporate social responsibility and integrated Strategy. Journal of Economics and Management Strategy, 10(1), 7-45. https://doi.org/10.1162/105864001300122548

Baumol, W. J., \& Oates, W. E. (1988). The Theory of Environmental Policy. Cambridge: Cambridge University Press. https://doi.org/10.1017/CBO9781139173513

Bruyu, De S. M. (1997). Explaining the Environmental Kuznets Curve: Structural Change and International Agreements in Reducing Sulphur Emissions. Environemnt and Development Economics, 24, 485-503. https://doi.org/10.1017/S1355770X97000260

Chen, L.., Yuan, B. L., \& Zhang, Y. P. (2019). Effect Assessment of Ecological Construction in China from 2008 to 2014. Pol.J.Environ.Stud, 28(3), 1241-1246. https://doi.org/10.15244/pjoes/85945

Copeland, B., \& Taylor, M. S. (2004). Trade, Growth, and the Environment. Journal of Economic Literature, 42, 7-71. https://doi.org/10.1257/.42.1.7

David, I. S. (2004). The Rise and Fall of the Environmental Kuznets Curve World Development, 32(8), 1419-1439. https://doi.org/10.1016/j.worlddev.2004.03.004

Dickey, D. A., \& Fuller, W. A. (1979). Distribution of Estimators for Time Series Regressions with a Unit Root. Journal of American Statistical Association, 74, 427-431. https://doi.org/10.1080/01621459.1979.10482531

Engle, R. F., \& Granger, C. W. J. (1987). Co-Integration and Error Correction: Representation, Estimation, and Testing. Econometrica, 55, 251-276. https://doi.org/10.2307/1913236 
Enders, W. (2010). Applied Econometric Time Series New York:John Wiley.

Fischer, C. (2011). Market Power and Output-Based -Refunding of Environmental Policy Revenues Resource and Energy Economics, 33(1), 212-230. https://doi.org/10.1016/j.reseneeco.2010.04.011

Granger, C. W. J., \& Newbold, P. (1974). Spurious Regressions in Econometrics. Journal of Econometrics, 2, 111-120. https://doi.org/10.1016/0304-4076(74)90034-7

Greenstone, M., \& Jack, K. B. (2015). Envirodevonomics: a research agenda for an emerging field. J. Econ. Lit., 53(1), 5-42. https://doi.org/10.1257/jel.53.1.5

Grossman, G. M., \& Krueger, A. B. (1991). Environmental Impacts of a North American Free Trade Agreement. National Bureau of Economic Research Working Paper. https://doi.org/10.3386/w3914

Grossman, G. M., \& Krueger, A. B. (1991). Economic Growth and the Environment. The Quarterly Journal of Economics, 110(2), 353-377. https://doi.org/10.2307/2118443

Gürlük, S. (2009). Economic Growth, Industrial Pollution and Human Development in the Mediterranean Region. Ecological Economics, 68, 2327-2335. https://doi.org/10.1016/j.ecolecon.2009.03.001

Harbaugh, W., Levinson A., \& Wilson, D. M. (2002) Re-examining the Empirical Evidence for an Environmental Kuznets Curve. The Review of Economics and Statistics, 84, 541-551. https://doi.org/10.1162/003465302320259538

Harford, J. D. (1978). Firm behavior under imperfectly enforceable pollution standards and taxes. Journal of Environmental Economics and Management, 5(26), 26-43. https://doi.org/10.1016/0095-0696(78)90003-7

Heyes, A. G. (2000). Implementing environmental regulation: enforcement and compliance Journal of Regulatory Economics, 17, 107-129. https://doi.org/10.1023/A:1008157410380

Johansen, S., \& Juselius, K. (1990). Maximum likelihood estimation and inference on cointegration with application to the demand for money. Oford Bulletin Economics and Statistics, 95, 615-628. https://doi.org/10.1111/j.1468-0084.1990.mp52002003.x

Jeyhun, I., Mikayilov, F., Hasanov, J., \& Marzio, G. (2018). Decoupling of CO2 emissions and GDP: A time-varying cointegration approach. Ecological Indicators, 95, 615-628. https://doi.org/10.1016/j.ecolind.2018.07.051

Jeffrey, R. (2018). Carbon tax - the latest tax on the poor. Available: https://www.fin24.com/Opinion/carbon-tax-the-latest-tax-on-the-poor-20180613 Retrieved on January 20,2019.

Keho, Y. (2010b). Budget Balance Through Revenue or Spending Adjustments? An Econometric Analysis of the Ivorian Budgetary Process. Journal of Economic and International Finance, 2(1), 1-11.

Khanna, M. (2002). Non-mandatory approaches to environmental protection. Journal of Economic Surveys, 15(3), 291-324. https://doi.org/10.1111/1467-6419.00141

Koop, G., Pesaran, M. H., \& Potter, S. M. (1996). Impulse Response. Analysis in Nonlinear Multivariate Models, Journal of Econometrics, 74, 119-147. https://doi.org/10.1016/0304-4076(95)01753-4

Koretelainen, M. (2008). Dynamic Environmental Performance Analysis:A Malmquist Index Approach. Ecological Economics, 64(7), 1-15. https://doi.org/10.1016/j.ecolecon.2007.08.001

Korhonen, P. J. \& Luptacik, M. (2004). Eco-efficiency Analysis of Power Plants:An Extension of Data Envelopment Analysis. European Journal of Operational Research, 154, 43-46. https://doi.org/10.1016/S0377-2217(03)00180-2

Kuosmanen, T., \& Kortelainen, M. (2005). Measuring Eco-efficiency of Production with Data Envelopment Analysis. Journal of Industrial Ecology, 9(4), 59-72. https://doi.org/10.1162/108819805775247846

Kuosmanen, T., \& Kortelainen, M. (2005). Eco-efficiency Analysis of Consumer Durables Using Absolute Shadow Prices. Journal of Productivity Analysis, 28, 57-69. https://doi.org/10.1007/s11123-007-0046-6

Kuosmanen, T., \& Marita, L. (2011). Efficient Environmental Policy with Interacting Pollutants. Environmental \& Resource Economics, 48(4), 629-649. https://doi.org/10.1007/s10640-010-9417-y

Kwiatkowski, D., Phillips, P. C. B., Schmidt, P., \& Shin, Y. (1992). Testing the Null Hypothesis of Stationarity Against the Alternative of a Unit Root, Journal of Econometrics, 54, 119-178.

Llorca, M., \& Meunie, A. (2009). SO2 Emissions and the Environmental Kuznets Curve: the case of Chinese Provinces Journal of Chinese Economic and Business Studies, 7(1), 1-16.

Lütkepohl, H. (2007). New Introduction to Multiple Time Series Analysis. Springer., 63. 
Macho-Stadler, I. (2008). Environmental regulation:choice of instrument under imperfect compliance Spanish Economic Review, 10, 1-21

Michael, T. (1995). Carbon dioxide emissions and global GDP Ecological Economics, 15(3), 215-223.

Mikayilov, J. I., Fakhri, J., \& Hasanov, M. G. (2018). Decoupling of CO2 emissions and GDP: A time-varying cointegration approach. Ecological Indicators, 95, 615-628.

Nelson, C. R., \& Plosser, C. R. (1982). Trends and Random Walks in Macro-economics Time Series: Some Evidence and Implications. Journal of Monetary Economics, 10, 139-162.

Panayotou, T. (1993). Empirical Tests and Policy Analysis of Environmental Degradation at Different Stages of Economic Development. Working Paper WP238, Technology and Employment Programme, International Labor Office, Geneva.

Panayotou, T. (1997). Demystifying the Environmental Kuznets Curve : Turning a Black Box into a Policy Tool. Environment and Development Economics, 2, 465-484.

Pesaran, H. H., \& Shin, Y. (1998). Generalized Impulse Response Analysis in Linear Multivariate Models, Economics Letters, 58, 17-29. https://doi.org/10.1002/jae.616

Pesaran, M. H., Shin, Y., \& Smith, R. J. (2001). Bounds testing approaches to the analysis of level relationships. Journal of Applied Econometrics, 16, 289-326.

Phillips, P. C. B., \& Perron, P. (1988). Testing for a unit Root in Time Series Regression. Biometrika, 75, 335-346. https://doi.org/10.1093/biomet/75.2.335

Piciu, G. C., \& Trică, C. L. (2012). Trends in the Evolution of Environmental Taxes. Procedia Economics and Finance, 3, 716-721. https://doi.org/10.1016/S2212-5671(12)00219-5

Requate, T. (2006). Environmental Policy under Imperfect Competition. International Yearbook of Environmental and Resource Economics, 2006/2007, Edward Elgar, 120-208. https://doi.org/10.4337/9781847200235.00011

Sherry, B., \& David, L. K. (2008). Economic Growth and the Environment:Theory and Facts. Resource and Energy Economics, 30, 115-149. https://doi.org/10.1016/j.reseneeco.2007.06.001

Shiota, N. (2008). Tax compliance and workability of the pricing and standards approach. Environmental Economics and Policy Studies, 9, 193-211. https://doi.org/10.1007/BF03353990

Stern, N, (2006). The Economies of Climate Change: The Stern Review.Cambridge, UK: Cambridge University Press, 2006. The International Energy Agency(IEA). https://www.iea.org/

Tullock, G. (1967). Excess Benefit. Water Resource Reserach, 3(2), 643- 644. https://doi.org/10.1029/WR003i002p00643

Wang, L. F. S., \& Conant, J. L. (1988). Corporate tax evasion and output decisions of the uncertain monopolist. National Tax Journal, 41(4), 579-581.

Wu, T. C., \& Yen, C. T. ( 2011). Tax evasion and monopoly output decisions in the presence of corporate social responsibility. Agriculture and Economics, 46, 85-101.

Yitzhaki, S. (1987). On the excess burden of tax evasion. Public Finance Review, 15(2), 123-137. https://doi.org/10.1177/109114218701500201

Yu, P. (2019). Taxing pollution and profits: A bargaining approach. Energy Economics, 78, 278-288. https://doi.org/10.1016/j.eneco.2018.11.018

Zheng, D. Z. (2011). Analysis of Carbon Emissions and Economic Growth Based on Spatial Econometrics Population, Resources and Environment in China, 5, 80-86.

Zhang, Y. J., \& Da Ya-Bin (2015). The decomposition of energy-related carbon emission and its decoupling with economic growth in China. Renewable and Sustainable Energy Reviews, 41, 1255-1266. https://doi.org/10.1016/j.rser.2014.09.021

\section{Copyrights}

Copyright for this article is retained by the author(s), with first publication rights granted to the journal.

This is an open-access article distributed under the terms and conditions of the Creative Commons Attribution license which permits unrestricted use, distribution, and reproduction in any medium, provided the original work is properly cited. 